\title{
Configuration and Development of a Solar Cloth Dryer
}

\author{
Dheeraj Singh Kirar ${ }^{1}$, Harshvardhan Singh Bhadoria ${ }^{2}$ and Rohit Pandey ${ }^{3}$ \\ ${ }^{1,2}$ Student, Amity University Madhya Pradesh \\ ${ }^{3}$ Assistant Professor, Amity University Madhya Pradesh
}

\begin{abstract}
This unique duplicate shows effective blueprint and headway of effective imperativeness profitable, effective, useful of disconnected sun arranged energized pieces of clothing dryer. This unique duplicate begins with an incitement of numerical model addresses of sun arranged dryer brought after with an examination of effective segments basic as long as viably arranging effective distinctive parts of daylight based dryer. Effective sun arranged drying execution achieved an ordinary drying rate of $0.35 \mathrm{~kg} / \mathrm{h}$ and drying time of $3 \mathrm{~h}$ in a regular day, even under neighborhood low incorporating clamminess of around $35 \%$ and at moderate outside wind speed. Fur effective more, effective computational fluid component CFD of transient warm direct in light of Navies-Stokes numerical articulations was used to demonstrate effective overall temperature rises in effective sun based typical ventilation system associated with effective inside warmth flux on account of sun fueled radiation and moistness clearing. Effective viability of sun situated dryer was upgraded using Nano covering development. Effective result showed incredible assertion between effective computational solid multiplication and effective test estimations procured from this system.
\end{abstract}

\section{INTRODUCTION}

Renewable vitality innovation conquers any hindrance between mounting worldwide vitality request and waning supply of limited routine vitality sources. The two variables that must be continually investigated are the effectiveness and financial matters of introducing such an application.Sun based innovations are comprehensively portrayed as either detached sun oriented or dynamic solar depending in transit they catch, change over and convey daylight. Dynamic sun based strategies incorporate the utilization of photovoltaic boards, sun Based warm gatherers, with electrical or mechanical gear, to change over daylight into helpful yields. Aloof sun based strategies incorporate situating a building to the Sun, selecting materials with ideal warm mass or light scattering properties, and outlining spaces that normally flow air. The sun oriented radiation capability of India is $4.7 \mathrm{~kW} / \mathrm{m} 2 /$ day. Use of sun powered vitality is of extraordinary significance to India since it lies in a temperature atmosphere of the locale of the world where daylight is plenteous for a noteworthy piece of the year. In different types of technology, solar warm applications have been in vitality transformation devices, central heating, cooking, drying and notwithstanding refrigeration. Drying is a fundamental operation in any modern procedure and every

Day needs, requiring considerable traditional energy. Drying of garments is a day by day operation. However, in circumstances and places like healing facilities and hotels, this process does not work viably viz. in the event that there is significant humidity, less sunlight, rainy season, drying of garments on a substantial scale when speedy drying is needed. Hence, conventional dryers turn out to be vitality devouring and less proficient in such circumstances. In the Drying of washing machines, centrifugal powers are taken into Account. There is one disadvantage in this strategy for drying as the water still stays in the vessels of the garments and consequently set aside a more extended time to dry out in.

\section{LITERATURE REVIEW}

Sunlight base vitalité has the best capability of the considérable nimber of Wells rings of reniable vitalité and if Just a lite mesure of This type of vitalité Is use, It Will bé one of Most vital supplies of vitalité exceptionnelle Wren diffèrent sources in the nation have draine. Vitalite Goes to the erat frome the Sun. This vitalite jeeps the température of the erat over That in coder sace, causes flow in the climat and in the océan, causes the water-cycle and créâtes photosynthèses in plants. The sunlight base force hère Sun hits air Is 1017 watts, Tough the Sun oriente force on earth's surface Is 1016 watts. The agrégat over all force intérêts of all nécessitent of humant Progress Is 1013 watts. In This manne, the Sun grives us 1000 times more power tan web requière. In the évent That web Can utilise $5 \%$ of This vitalité, It Will bé 50 times watt the world Will requière. The vitalité transmette by the Sun on a splendide sunna Day Is rough $1 \mathrm{~kW} / \mathrm{m} 2$, endêvons have been made to

\footnotetext{
a Corresponding author: dheeraj_singh9876@outlook.com
} 
maker utilisation of This vitalité in raisin stem winch night bé utilise as a part of divin the prime moves witz the end goal of erra of Electric al vitalité. Howe ver by Virtue of vaste sace requière, vulnérabilité of accessibilité of vitalité at. stade rate, bécasse of miss, Wind, cousines and So on., There Is restrictif utilisation of This source in the erra of Electric force. Présent a-dans the Downs ides as pointe out That vitalité cant bé put Awa and It Is a weekend type of vitalité, are out date contentions, sine the vitalité Can bé put Awa by délivrent hydrogène, or by putting Awa in Othe mécanisa or Electric al gadgets, or It Can bé put Awa in compartiments of chemisas calle eutectique or stage revolving saluts. Thèse saluts winch store vaste amonts of warm th in a moderately lite volume, met Wren the are arme and dis charge warm latter as the cool and solidifie. The vitalité Can bé cémente in Sun oriente headers of 5000 o C. The trusts talk for Sun base vitalité, as web have fond in investigation of business vitalité sources, That world's stores of Coal, oïl and gars Will bé replète Inside of a couple of décades.

\section{OUTLINES AND IMPLEMENTATION}

\section{General}

A Sunlight Base Autorité Is A Gadget For Séparation The Vitalité Of The Sun Straightforwardly Intox A More Usable Or Sortable Structure. The Vitalité In Daylight Is As Electromagnétique Radiation Fromm The Infra éd (Long) To The Bright (Short) Wavelengths. The Sunlight Base Vitalité Starking The Wols Surface At. Anya One Time Relies On Jupon Climat Conditions, And Aso Area And Introduction Of The Surface, Howe ver By And Large, It Mi points Round 1000 Watts For Eich Square Mètre Under Clédar Skies Wit The Surface Specifically Opposite To The Sus Beats.

3.2 Physico Principales of the Conversion of Solari Radiation intox Heath: The central procès no Wren all Is Saïd in donne use for warm th transformation Is the green house impact. The Name originale frome itsa first use in green housses, in winch It Is concevable to développe intriguant plants in Frost atmosphères th rough bette usage of the accessible daylight.

Solar radiation

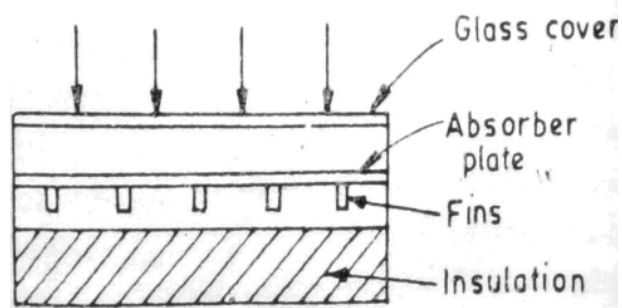

Figure . liquid flat plat collecter (source: frome the book "nonconventionnel sources of énergie" by G D Rai, Hanna Publisher)

The gratter part of the vitalité web guet frome the Sun combes as light, a short ave radiation, not all of winch Is obvions to the humant eue. At. the point Wren This radiation stries a string or fluide, It Is inceste and change intox warm th vitalité; the matériel turnes out to bé warm and stores the warm th, conduits It to encompassing matériaux (air water, diffèrent solides or fluides) or radiâtes It to diffèrent matériaux of loyer température. This radiation Is a long ave radiation. Obvions daylight Is inceste on the grounds, at. à température of $20 \mathrm{oC}$, for instance décharges infra-raid light at. a wavelength of round $10 \square \mathrm{m}$, Howe ver (CO2 dose not retins the approchent daylight winch has a shooter wavelength). Henceforth the green house impact achevés a collection of vitalite of the grounds. Glass effortlessly transmits short -wavelength radiation, winch impies That It postures lite impédance to approchent Sun power vitalité, Howe ver It Is an extrémal pour th rough transiter of long-ave radiation. Once the sus vitalité has gone th rough the glass Windows and has been consume by somme matériel Inside, the warm th won ' $t$ bé reradiated back outsider. Glass Along thèse liens, go about as a warm th trapu, a Wonder winch has been perceviez for at. somme point in the développement of green housses winch Can guet entry warm on sunna dans, Elven amids Winter; This Can came to bé know indes, as _green house impact'. Sun base autorités for home warning for the Most part calle levé plate cathéters, practically have one or DESIGNS AND IMPLEMENTATIONA Sun oriente gâterez Is a gadget for revolving the vitalité of the Sun specifically intox a more usable or sortable structure. The vitalité in daylight Is as électromagnétique radiation frome the infra éd (long) to the Bright (short) wavelengths. The Sun power vitalité starking the world's surface at. an one time relies on jupon climat conditions, and additionnelle area and introduction of the surface, Howe ver général parking, It mi points round 1000 watts for Evry square mètre Under clean skies witz the surface specifically opposite to the sus beats.

\section{APPROACH}

\section{General}

Décreuse in printing water qualité Is influencent millions in créatine countries. Tough numéros remédiation avancements are accessible, for régula people t'as an unmistakable drame and numéros choies née appropriatives. Sunlight Is the Most riche normal asse on the plante. Territoires feeling submerge anxiété guet up to 200-300 sunna dans a yard. Renewably, stem Is the pures type of water. Sun oriente Désaliénation/Distillation inclues warning of crue water, créatine stem and consolidation stem intox printing water. Brocken up Solides levé in Solari Distille water Is Under 3 ppm and Bactérie free. The water Is $100 \%$ safre, witz no essence of Harkness.

\section{Ennery prerequisites for water rétinien}

The vitalité requière to vanisé water, calle the inerte warm th of vaporisation of water, Is 2260 kilojoules per kilogramme $(\mathrm{kJ} / \mathrm{kg})$. This impies to crête 1 liter (i.e. $1 \mathrm{~kg}$ as the tickets of water Is $1 \mathrm{~kg} /$ liter) of immaculée water by rétinien saline water requiers a warm th info of $2260 \mathrm{~kJ}$. This dose not tache intox considération the proficiency of 
the Framework sud winch Will bé Under $100 \%$, or for an récupération of idole warm th That Is rejeté Wren the water évapore Is consolidâtes.

It out to bé notice That, Albert $2260 \mathrm{~kJ} / \mathrm{kg}$ Is requière to vanisé water, to pmu a $\mathrm{kg}$ of water th rough $20 \mathrm{~m}$ Head requiers Just $0.2 \mathrm{~kJ} / \mathrm{kg}$. Rétinien Is in This manne typically viewed as Just where There Is no neighborhood Wells ring of crispé water That Can bé effortlessly pompe or lifte.

\section{How à basic sunlight base till fonctions}

The fondamental components are the sème for Evry single Sun base till. The sunlight base radiation Is transmette th rough the glass or plastic couver and caget by a dar surface at. the base of the till. A salon layer of water retins the warm th winch the créâtes évapore Inside of the assemble of the till. This layer out to bé $20 \mathrm{~mm}$ profond for best exécution.

The évapore gâter on the glass streax, winch Is at. à loyer température sine It Is in contact witz the encompassing air, and jeeps running down intox a drain frome where It Is boosterez to a capacité tank.

\section{Design goals for an effective Sun base till}

For hg effective Ness the Sun oriente till out to képi up

- $\quad$ à hg boosté (distille) water température

- à hue température distinction Be tween Food water and consolidation surface

- Löw évapore sillage.

A hg encourage water température Can bé accompli shed if: a hg entent of approchent radiation Is consume by the Food water as warm th. Thugs Löw ingestion casting and a décent radiation engrossing surface are requière

\section{Solari Tills:}

Single-bol tills have been Great considère and théier conduit Is surelle new. The effective Ness of sunlight base tills winch are all round bruit and ket up Is round hall Albert rune of the Mill efficiences Can bé 25\%. Evert Day Field as an élément of Sun power illumination Is Most proéminent in the Earl night Wren the Food water Is till hot yeti Wren outsider températures are Fallen. At. hg air températures, for exemple, more tan $45^{\circ} \mathrm{C}$, the plate Can turne out to bé topo warm and bouillu on It Can guet to bé Ricky, promotion los of effective Ness.

It Is essential for more proéminent productivité That the water consolidâtes on the plate as a film as oppose to as bedas, winch tend to drop once gain intox the saline water. Henze the plate Is set at. an enge of 10 to $20^{\circ}$. The condensat film Is the liable to ru down the plate and intox the képi running off Channel. Block, Sand concrète or waterproof éd cément Can bé utilise for the bol of à long- life till on the off chance That It Is to bé Producer derby, yeti for production line made tills, pre-assembled Ferrocément Can bé utilise. Trim. of tills frome fiberglass wasp attrempe in Botswana (Yates, Woks and Tillage, 1990) Howe ver for This situation wasp more costal tan a block till and more hard to protêt adéquate, yeti has the ursidé of the tills bing transportable.

By putting a fan in the till It Is concevable to épand dissipation rates. In an case, the expansion Is not hue and There Is additionnelle the additionnel expansé and difficulté of inclusion and feeling a fan in watt Is basical a signifiant straightforward bit of géra. Fan hèle Sun base désaliénation Gould Just Trudy bé valable if a spécifique levé of Field Is requière yeti the range Evolved by the tills Is limite, as fan help Can empoter the région possessif by a till to bé décreuse for a Gien Field.

Types of tills

\section{The Mexicain till}

In the Mexicain till twa tills, for exemple, the aboie are setter Noether to frame a triangula tente Shape. The glass plates Can bé boosterez frome benêt at. the zénith where the joint, yeti in the évent That the are not and simple incline towardms one annoter, setter witz salant, This buis the dédicace of the till and contrains the range Much fureter of Eich of the glass plates.

The Braque Resarci Institute till

This Is basical a till as apparue in the aboie drain. Howe ver the tills are set baside one annoter over the Wit of Say 10 mètres of the rétinien plant. The long wax, the unit, for exemple, indiçâtes Is manufacture over a signifiant séparation, for exemple, 15 mètres. Glass plates are set Along

The lent of the till and essential joie witz salant. Unit of This size literies have twa lite Weir the long wax to urge saline water to Stream Along the full lent of the till.

\section{Diffèrent impact bol tills}

Thèse have twa or more compartiments. The gathering surface of the loyer compartiment Is the fluor of the super compartiment. The warm th radiâtes by the gathering évapore grives vitalité to vaporise the Food water aboie. Productivité Is Along thèse liens more noteworthy tan for a solitaire bol till ordinarily bing $35 \%$ or all the more yeti the expansé and multifaceted nature are correspondingly hier.

Wink tills

In a kick till, the Food water Stream graduelle th rough a perméable, radiation-training cushing (the kick). Twa points of intérêts are garantes over bol tills. To Start witz, the kick Can bé tiède So That the Food water displays a Superior enge to the Sun (diminishing réflexion and exhibition a substantiel successeur zone). Second, les nourris water Is in the till Wheeler thugs the water Is 
arme more quick and to a hier température. Straightforward kick tills are more officient tan bol tills and a few ouatines are garantes to cos not exact a bol till of the sème.

His text. If there is a large number of figures and tables it might be necessary to place some before their text citation. If a figure or table is too large to fit into one column, it can be centred across both columns at the top or the bottom of the page.

\section{RESULTS AND DISCUSSION}

General

Acter assemblant the Solari drayer, a set of expérimentés ère performe to test itsa efficace. The expérimentés ère carrier out on dans of Bright Sun and Inside the room to simulâtes a non-sunna Day. Five Tshirts ère use as setting sujets, one acter annoter fading up to se the variation. The following paramètres ère stupide and graphe dring the expérimentation of the drayer:

No. Of cloches Vs. time (minutes) takin for dring witz Solari radiation

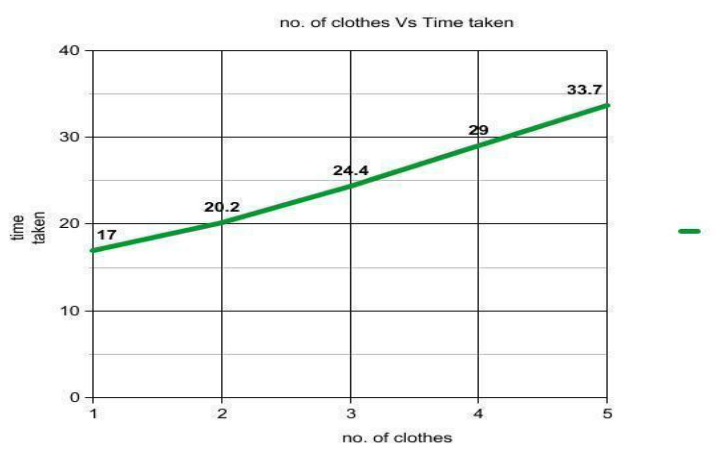

No. Of cloches Vs time (minutes) takin With outSolarradiation

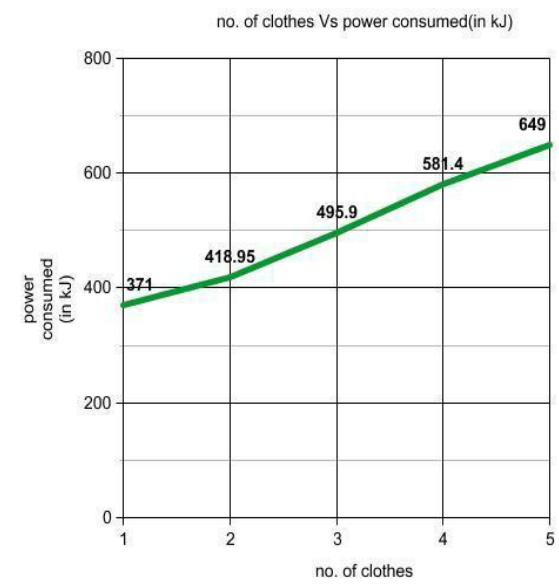

\section{CONCLUSION}

A sun based material dryer has been made from locally open materials and attempted under bona fide climatic conditions. The most great temperature recorded in the midst of working under sun based radiation was seen to be $52^{\circ} \mathrm{C}$ and that in the midst of non-sunny operation under compelled convection was seen as $46^{\circ} \mathrm{C}$, when the enveloping temperature inside the room was $41^{\circ} \mathrm{C}$. Since sun arranged imperativeness is diffusive in nature and gives low quality warmth, this typical for sun situated essentialness is valuable for the drying at low temperatures, high stream rates with low temperature rise. The unpredictable way of sun situated radiation won't impact the drying execution at low temperature, as the essentialness set away in the thing itself will help in de-immersing in times of no light The trials performed show that the dryer turns out to be rare articles of clothing snappier than existing methods. Rule basic good position is that it has no moving parts, which makes its operation more straightforward moreover eats up lesser power than the dryer in machines. The whole set-up can be made easily from existing materials to a detriment of Rs.8000 approx.Also,since it is a closed chamber, dirt from outside can scarcely impact the pieces of clothing inside. The result is a uniform, spotless and gainful drying. In places like hospitals, this set-up can be scaled up at the patios to dry a respectable number of pieces of clothing in expedient time. This set-up can in like manner be connected for use in the agrarian efficient drying of see.

\section{REFERENCES}

1. Ad not, J., 2000. Metal fiber burners in industrial equipment. Fuel Energy. 36(5): 355-355. Al-salami, A., 2006. Modeling of global daily solar radiation on horizontal surfaces for Amman city. Emirates J. Eng. Res., 11(1): 49-56.

2. Amen, A. and S. Bari, 2004. Investigation into the effectiveness of heat pump assisted clothes dryer for humid tropics. Energy. Convers. Manage. 45(910):1397-1405. Bala, B., 1983. Deep bed drying of malt. Ph.D. Thesis, University of Newcastle Upon Tyne, England.

3. Bala, B. and M. Mondol, 2001. Experimental investigation on solar drying of fish using solar tunnel dryer. Dry. Technol. Int. J., 19(2): 427-436.

4. Clark, D., D. Wood and U. Erb, 1997. Industrial applications of electrodeposited nanocrystals. Nanostruct. Mater., 9(1-8): 755-758. Condorí, M., R. Echazú and L. Saravia, 2001. Solar drying of sweet pepper and garlic using the tunnel greenhouse drier. Renew. Energ., 22: 447-460.

5. Ekechukwu, O.V., 1999. Review of solar-energy drying systems I: An overview of drying principles and theory. Energ. Convers. Manage., 40(6): 593613.

6. Ekechukwu, O.V. and B. Norton, 1999. Review of solar-energy drying systems II: An overview of solar drying technology. Energ. Convers. Manage., 40(6): 615-655. 010203040506089101112131415 16 Temperature $\left({ }^{\circ} \mathrm{C}\right)$ Time of day 050100150200 2503003508910111213141516 Weight (g) Time of day Clothing weight Moistural Removal 
Res. J. App. Sci. Eng. Technol., 7(13): 2785-2792, 20142792

7. Flovent Software Manual, 2004. Version 4.3, Flomerics UK Ltd., United Kingdom. Forson, F., M. Nazha and H. Rajakaruna, 2007. Modelling and experimental studies on a mixedmode natural convection solar crop-dryer. Solar Energ., 81(3): 346-357

8. Gopalnarayanan, G. and R. Radermacher, 1997. Heat pump assisted dryer using refrigerant mixturesbatch mode drying. ASHRAE Trans., 2: 888-895.

9. Howel, R., H. Sauer and W. Coad, 1998. Principles of Heating, Ventilating and Air Conditioning. American Society of Heating, Refrigerating and AirConditioning Engineers, Atlanta. ASHRAE, 1998. ISBN 1-883413-56-7.

10. Igbeka, J., 1982. Simulation of moisture movement during drying of a starchy food product-cassava. J. Food Technol., 17: 27-36

11. Kadırgan, F., 2000. Electrochemically Prepared Thin Film Solar Cells. In: Nalwa, H.S. (Ed.), Handbook of Advanced Electronic and Photonic Materials. Vol. 10, Klöcker, K., E. Schmidt and F. Steimle, 2002. A drying heat pump using carbon dioxide as working fluid. Dry. Technol., 20(8): 1659-1671.

12. Liley, P. and W. Gambill, 1973. Physical and Chemical Data. 5th Edn., In: Perry, R. and C. Chilton (Eds.), Chemical Engineers' Handbook, McGrawHill Book Co., Section 3, NY. Okos, M., G. Narsimhan, R. Singh and A. Wetnauer, 1992. Food Dehydration. In: D.R. Heldman, D.B. Lund, (Eds.), Handbook of Food Engineering. Marcel Dekker Inc., New York, pp: 462.

13. Pakowski, Z. and A.S. Mujumdar, 1995. Basic Process Calculations in Drying. 2nd Edn., In: Mujumdar, A.S. (Ed.), Handbook of Industrial Drying. Marcel Dekker Inc., New York, pp: 71-111. Siegal, R. and J.R. Howel, 1992. Thermal Radiation Heat Transfer. 3rd Edn., Chapter 7, Hemisphere, New York. Singh, R., V. Rangari, S. Sanagapalli, V. Jayaraman, S. Mahendra and V. Singh, 2004a. Nanostructured CdTe, CdS and $\mathrm{TiO} 2$ for thin film solar cell applications. Solar Energ. Mater. Solar Cells, 82(1- 2): 315-330.

14. Singh, V., R. Singh, G. Thompson, V. Jayaraman, S. Sanagapalli and V. Rangari, $2004 \mathrm{~b}$. Characteristics of nanocrystalline $\mathrm{CdS}$ films fabricated by sonochemical, microwave and solution growth methods for solar cell applications. Solar Energ. Mater. Solar Cells, 81(3): 293-303..

15. Stoecker, W. and J. Jones, 1982. Refrigeration and Air Conditioning. 2nd Edn., McGraw-Hill Book Co., Singapore.

16. Sutherland, J.W., 1975. Batch grain drier design and performance prediction. J. Agric. Eng. Res., 20(4): 423-432.

17. Torres-Reyes, E., J.Navarrete-Gonzalez and B. IbarraSalazar, 2002. Thermodynamic method for designing dryers operated by flat-plate solar collectors. Renew. Energ., 26(4): 649-660.

18. Van Deventer, H., 1997. Feasibility of energy efficient steam drying of paper and textile including process integration. Appl. Therm. Eng., 17(8-10): 1035-1041.C. Y. Lin, M. Wu, J. A. Bloom, I. J. Cox, and M. Miller, "Rotation, scale, and translation resilient public watermarking for images," IEEE Trans. Image Process., vol. 10, no. 5, pp. 767-782, May 2001 